\title{
Column Biosorption of Lead, Cadmium, Copper, and Arsenic ions onto Algae
}

Abbas H. Sulaymon ${ }^{1}$, Ahmed A. Mohammed ${ }^{2}$ and Tariq J. Al-Musawi ${ }^{3 *}$

${ }^{1}$ Professor and Head of Energy Engineering Department, Baghdad University, Iraq

${ }^{2}$ Assistant Professor, Environmental Engineering Department, Baghdad University, Iraq

${ }^{3}$ Environmental Engineering Department, Baghdad University, Iraq

\begin{abstract}
A mixture of green and blue-green algae was used as an adsorbant material for biosorption of lead, cadmium, copper, and arsenic ions in fluidized bed reactor. Batch experiments showed that the algal biomass was successfully used for the removal of these metal ions from wastewater. The maximum percentage removal for $1 \mathrm{~g}$ dose was 89 , 82,79 , and 70 for $\mathrm{Pb}^{2+}, \mathrm{Cu}^{2+}, \mathrm{Cd}^{2+}$ and $\mathrm{As}^{3+}$, respectively. The experimental data fit well to an ion exchange equilibrium model. Affinity constants were calculated for each metal. A higher affinity of the biomass towards lead $\left(\mathrm{Pb}^{2+}\right)$ was observed due to the high electronegativity of this metal. FTIR analyses showed that hydroxyl and carboxyl groups could be very effective for capturing these metals. An ideal plug flow model was adopted to characterize the fluidized bed reactor and solved numerically using MATLAB version (R2009b), which fit well to the experimental breakthrough data. The effects of different operating conditions such as: static bed height, superficial velocity and particle diameter on the removal process were investigated. Lead showed the largest operating time compared with others.
\end{abstract}

Keywords: Algae; Metals; Ion exchange; Fluidized bed; Breakthrough curve

\section{Introduction}

One of the most challenging environmental problems today is the removal of heavy metals and other toxic contaminants from industrial wastewater. Many aquatic environments face metal concentrations that exceed water quality limits designed to protect the environment, animals, and humans [1]. Metals hazardous to humans include lead, cadmium, mercury, arsenic, copper, zinc, and chromium. Arsenic is carcinogenic metal. Cadmium can cause bone and kidney damage. Copper and lead can cause brain and bone damage [2].

Biosorption is an innovative technology that employs inactive and dead biomass for the removal and recovery of metals from aqueous solutions [3-5]. Biomass from various sources such as bacteria, yeast, algae, fungi and plants have been used to adsorb metal ions from the environment [6-9]. Among the most promising types of biosorbents studied is algal biomass $[10,11]$. Algal biomass has been reported to have a high metal binding capacity due to the presence of polysaccharides, proteins or lipids on the cell wall structure which contain functional groups such as amino, carboxyl, hydroxyl, sulfate, and others [12]. These groups have the ability to bind heavy metals by donation of an electron pair from these groups to form complexes with the metal ions in solution [13].

Recently, biosorption in columns and its modeling have been receiving more attention. Fixed and fluidized bed reactors have been used widely by the chemical industry, pharmaceutical industry, food industry, wastewater treatment and for recovery of different substances [14]. Fluidized bed systems are common and important reactors in process engineering because of the good mass and heat transfer rate between the fluid and the particles, and between the particles and the side wall of the column [15].

The previous literature does not include much information on biosorption of metal ions by the algal biomass with fluidized bed reactors. Therefore, the main objectives of this work are: (i) to characterize the physiochemical parameters of algal biomass such as specific surface area, particle porosity and active groups; (ii) to evaluate the application of an ion exchange model in a batch reactor; (iii) to evaluate and model the breakthrough curves of lead, cadmium, copper, and arsenic using fluidized bed of algal biomass; (iv) to evaluate the effects of some experimental conditions on the removal of these metal ions such as superficial velocity, bed height, and particle diameter.

\section{Theoretical models}

Equilibrium model: Several studies concluded that ion exchange is a principal mechanism of biosorption by dead algae [14,15]. The ion exchange isotherm model is a good representation of the biosorption process on algae, since it reflects the fact that most algal biomass contains light metal ions such as $\mathrm{K}^{+}, \mathrm{Na}^{+}$, and $\mathrm{Mg}^{2+}$ ions, which are released upon the binding of a heavy metal cation [11]. Therefore, it has been demonstrated that the binding of metals by algal biomass from aqueous solution can be described by the following ion exchange reaction $[16]$ :

$$
\mathrm{M}^{2+}+\text { (L-Biomass) (M-Biomass) }+\mathrm{L}^{2+}
$$

Where, $\mathrm{M}^{2+}$ and $\mathrm{L}^{2+}$ represent the divalent metal cations sorbed and released from the biomass.

The total normality, which represents the sum of the equivalent concentrations of all competing cations that can be exchanged during the reaction, remains the same when equilibrium is achieved; hence, the total normality is expressed by:

$$
C_{T}=C_{M}+C_{L}
$$

Where, $\mathrm{c}_{\mathrm{M}}$ is the total normality of heavy metals that remain in the *Corresponding author: Tariq J. Al-Musawi, Environmental Engineering Depart-
ment, Baghdad University, Iraq, E-mail: tariqjwad@yahoo.com

Received April 04, 2013; Accepted May 27, 2013; Published June 25, 2013

Citation: Sulaymon AH, Mohammed AA, Al-Musawi TJ (2013) Column Biosorption of Lead, Cadmium, Copper, and Arsenic ions onto Algae. J Bioprocess Biotech 3: 128 doi: 10.4172/2155-9821.1000128

Copyright: (C) 2013 Sulaymon $\mathrm{AH}$, et al. This is an open-access article distributed under the terms of the Creative Commons Attribution License, which permits unrestricted use, distribution, and reproduction in any medium, provided the original author and source are credited. 
liquid phase, $c_{L}$ is the total normality of light metals released into the liquid phase, and $\mathrm{c}_{\mathrm{T}}$ represents the total normality of the solution.

The total number of exchangeable binding sites $(\mathrm{Q})$ is the sum of the amount of adsorbed and released metals:

$$
Q=q_{M}+q_{L}
$$

Where: $\mathrm{q}_{\mathrm{M}}$ is the amount of adsorbed heavy metal (meq/g); $\mathrm{q}_{\mathrm{L}}$ is the amount of released light metal into the solution due to biosorption of heavy metal (meq/g).

The equivalent fraction of one component in the liquid phase $\left(\mathrm{x}_{\mathrm{M}}\right.$, $\mathrm{x}_{\mathrm{L}}$ ) is the ratio between its own concentration in the liquid phase and the total normality of the solution $\left(\mathrm{c}_{\mathrm{T}}\right)$, whereas the equivalent fraction in the solid phase $\left(\mathrm{y}_{\mathrm{M}}, \mathrm{y}_{\mathrm{L}}\right)$ is the relation between its own concentration in solid phase divided by the total number of exchangeable binding sites $(\mathrm{Q})$ :

$$
\begin{array}{ll}
x_{M}=\frac{c_{M}}{c^{0}}, & x_{L}=\frac{c_{L}}{c^{0}} \\
y_{M}=\frac{q_{M}}{Q}, & y_{L}=\frac{q_{L}}{Q}
\end{array}
$$

Based on sorption reaction, the affinity constant $\left(\mathrm{K}_{\mathrm{M}, \mathrm{L}}\right)$ represents the relative power exchange of the heavy metal to the light ions and it is defined by [17]:

$$
K_{M, L}=\frac{y_{M} \cdot x_{L}}{x_{M} \cdot y_{L}}
$$

Where, the subscript $\mathrm{M}$ and $\mathrm{L}$ refer to the heavy metal and light metal in the solution.

Rearranging the above equation by substituting the light metal equivalent fraction, the model equation for the equilibrium uptake of a heavy metal ion in the presence of light metals can be written in the form of the following equation:

$$
y_{M}=\frac{K_{M, L} \cdot x_{M}}{1+\left(K_{M, L}-1\right) \cdot x_{M}}
$$

The evaluation of fitness of the equilibrium model equation with experimental data requires an error function with optimization [18]. The experimental equilibrium data for the biosorption of four metals were fitted with the ion exchange equilibrium model (Eq.7). The equilibrium model parameter (affinity constant) was evaluated and optimized by non-linear regression using STATISTICA program version 6. The model's fitness was significant as indicated by the coefficient of determination $\left(R^{2}\right)$ where a large $R^{2}$ value indicates a better fit.

Breakthrough curve models: A model of fluidized bed is shown in Figure 1. Three assumptions were made to constrain the model for fluidized bed: (i) the concentration is uniform in the radial direction, (ii) there is no material product in the reactor, (iii) the fluid stream is an ideal plug flow [19]. With these assumptions, the following equations can be obtained:

Rate of pollu $\tan t$ conc. at any depth

$=($ Rate of input conc. by conective flow $)+($ Rate of input conc. by dispersion $)-($ Rate of output conc. by convective flow $)$

$-($ Rate of output conc. by dispersion $)-($ Solute lost by sorption $)$

$\frac{\partial C}{\partial t} \cdot d z=\frac{U}{\varepsilon} \cdot C+E_{z} \cdot \frac{\partial C}{\partial z}-\frac{U}{\varepsilon}\left[C+\frac{\partial C}{\partial z} d z\right]-E_{z} \cdot\left[\frac{\partial C}{\partial z}-\frac{\partial}{\partial z}\left(\frac{\partial C}{\partial z}\right) d z\right]-\frac{(1-\varepsilon)}{\varepsilon} \rho_{P} \frac{\partial q}{\partial t} d z$

where $U$ is the superficial velocity $(\mathrm{m} / \mathrm{s}), \varepsilon$ is the bed void fraction, $\mathrm{C}$ is the concentration of metal at any time $(\mathrm{mg} / \mathrm{l}), \mathrm{E}_{\mathrm{z}}$ is the axial dispersion coefficient $\left(\mathrm{m}^{2} / \mathrm{s}\right), \mathrm{z}$ is the bed height $(\mathrm{m}), \mathrm{t}$ is the time, and $\mathrm{q}$ is the amount of adsorbed metal ion $(\mathrm{mg} / \mathrm{g})$.
Equation (9) was simplified to the following:

$\frac{\partial C}{\partial t}=E_{z} \frac{\partial^{2} C}{\partial z^{2}}-\frac{U}{\varepsilon} \frac{\partial C}{\partial z}-\frac{(1-\varepsilon)}{\varepsilon} \rho_{P} \frac{\partial q}{\partial t}$

The mass balance for the solid phase is expressed as:

$(1-\varepsilon) \rho_{P} \frac{\partial q}{\partial t}=K_{L a}\left(C-C^{*}\right)$

where $\mathrm{C}^{*}$ is the equilibrium heavy metal concentration ( $\left.\mathrm{mg} / \mathrm{l}\right), \mathrm{K}$ is the mass transfer coefficient, and a is the specific surface area $\left(\mathrm{m}^{2} /\right.$ $\mathrm{m}^{3}$ ). Substituting Eq. (11) into Eq. (10), the following equation can be obtained:

$\frac{\partial C}{\partial t}=E_{z} \frac{\partial^{2} C}{\partial z^{2}}-\frac{U}{\varepsilon} \frac{\partial C}{\partial z}-\frac{K_{L} \cdot a}{\varepsilon}\left(C-C^{*}\right)$

The initial and boundary conditions are:

$$
\begin{aligned}
& 0<\mathrm{z}<\mathrm{H}, \mathrm{t}=0 ; C=C^{*}=0 \\
& \mathrm{z}=0, \mathrm{t} \geq 0 ; C=C_{i} \\
& \mathrm{z}=\mathrm{H}, \mathrm{t}>0 ; \frac{\partial C}{\partial z}=0
\end{aligned}
$$

Where: $\mathrm{H}$ is the bed height $(\mathrm{m}), \mathrm{C}_{\mathrm{i}}$ is the initial metal concentration (mg/l).

The partial differential equation (Eq. 12) with its initial and boundary conditions was solved numerically using MATLAB software Version (R2009b). The experimental breakthrough data for biosorption of the four metals were fitted to a theoretical model data obtained from the solution of equation (12). The model's fitness was determined to be significant by the coefficient of determination $\left(R^{2}\right)$.

\section{Materials and Methods}

\section{Materials}

Adsorbent preparation: Mixture of green (Chlorophyta) algae and blue-green (Cyanobacteria) algae was used as a biosorbent material. The algae were collected in April and September 2011 from the irrigation canal of Baghdad University/Iraq. The foreign matter was removed from the algae and washed several times with tap water and distilled water to remove impurities and salts. Sample of $0.5 \mathrm{~kg}$ of collected algae were analyzed for species composition and percentage weight using a microscope according to the standard methods [20]. The species and percentage weight were Oscillatoria princeps (92\%), Spirogyra aequinoctialis (3\%), Oscillatoria subbrevis (2\%), Oscillatoria Formosa (1\%), and others (1\%). The washed algae were sun dried and then dried in oven at $50^{\circ} \mathrm{C}$ for $48 \mathrm{~h}$. The dried algal biomass was shredded, ground in a mortar, sieved and stored in an opaque polyethylene container at room temperature. Two mesh sizes of 0.4-0.6 and 0.6-1 mm particle diameter were used for biosorption experiments. The biomass particle size distribution was determined using a set of standard sieves. Since the algal biomass could swell in water, the biomass was initially soaked in water and then wet sieved.

A sample of powdered algal biomass was analyzed for physical properties such as particle density, surface area, particle porosity and bed void fraction. The surface area of algal biomass was determined from $\mathrm{N}_{2}$ adsorption isotherm using a Micrometrics Nano Porosity System. In order to identify functional groups (carbonyl, carboxylic, hydroxyl and others), Fourier Transform Infrared spectra (FTIR) techniques were used. The FTIR offers excellent information on the nature of the bands present on the surface of the algae before and after the biosorption process. 
Adsorbate preparation: All chemicals used in this work were analytical reagent grade and were used without further purification. Lead, cadmium, copper, and arsenic ion solutions were prepared by dissolving the corresponding analytical salts of $\mathrm{Pb}\left(\mathrm{NO}_{3}\right)_{2} \cdot 2 \mathrm{H}_{2} \mathrm{O}$, $\mathrm{Cd}\left(\mathrm{NO}_{3}\right)_{2}, \mathrm{Cu}\left(\mathrm{NO}_{3}\right)_{2} \cdot 3 \mathrm{H}_{2} \mathrm{O}$ and $\mathrm{As}_{2} \mathrm{O}_{3}$, respectively in distilled water. The diluted solutions were kept in a glass container at room temperature. A solution with a concentration of $50 \mathrm{mg} / \mathrm{l}$ of each metal was used as adsorbate material. The concentration of each metal was measured using a flame Atomic Absorption Spectrophotometer (AAS, type: SHIMADZU, Model: 7200, JAPAN). Before the biosorption process was initiated, the $\mathrm{pH}$ of each solution was adjusted to the required value (2, $3,4,5$, and 6) by adding $0.1 \mathrm{M} \mathrm{HNO}_{3}$ or $0.1 \mathrm{M} \mathrm{NaOH}$ solutions. All the glassware used for dilution, storage and experimentation were cleaned with detergent, thoroughly rinsed with tap water, soaked overnight in a $20 \% \mathrm{HNO}_{3}$ solution and finally rinsed with distilled water before use.

\section{Methods}

Effect of experimental parameters: The effects of $\mathrm{pH}$, contact time, temperature, and initial heavy metal concentration on the removal efficiency were studied in a batch reactor. All the study experiments were carried out in $250 \mathrm{ml}$ flasks containing $100 \mathrm{ml}$ of metal solution and a $1 \mathrm{~g}$ dose of algal biomass. Effect of $\mathrm{pH}$ was measured using a $50 \mathrm{mg} / \mathrm{l}$ metal concentration at room temperature, and the $\mathrm{pH}$ range was from 2-6. Effect of contact time was measured using $50 \mathrm{mg} / \mathrm{l}$ heavy metal concentration at room temperature and the $\mathrm{pH}$ was fixed at 4 for all metal solution. The temperature effect experiment was conducted using $50 \mathrm{mg} / \mathrm{l}$ heavy metal concentration, and the solution temperatures were $10,20,30,40$, and $50^{\circ} \mathrm{C}$. Effect of initial heavy metal concentrations were conducted using 10,50 and $100 \mathrm{mg} / \mathrm{l}$ heavy metal solutions at room temperature.

Different operating conditions were used in the fluid bed experiments, i.e., changing static bed height, fluid superficial velocity and particle diameter. The effect of bed height of the algal biomass on the biosorption process was investigated at heights of 2.5, 5.0, and $7.5 \mathrm{~cm}$. The influence of superficial flow velocity upon adsorption performance was measured by establishing the breakthrough curves at $10 \%$ and $50 \%$ above the minimum fluidization velocity. Two particle diameter ranges were used in the column experiments of 0.4-0.6 and 0.6-1.0 mm.

Equilibrium experiments: Equilibrium experiments were carried out at different weights of algal biomass $(0.05,0.1,0.3,0.5,0.8,1,2$, and $3 \mathrm{~g}$ ). Each weight was thoroughly mixed with $100 \mathrm{ml}$ of heavy metal solution at $50 \mathrm{mg} / \mathrm{l}$ concentration. Eight flasks of $250 \mathrm{ml}$ capacity were placed in a rotary shaker type (Edmund Buhler, 7400 Tubingen Shaker-SM 25, Germany) at $200 \mathrm{rpm}$ for $3 \mathrm{~h}$ to obtain equilibrium. It was found from the preliminary experiments that these conditions lead to equilibrium conditions. The mixtures were then filtered using filter paper (type: WATMAN No.42, ash less, diameter $7 \mathrm{~cm}$ ), then the residual concentration of lead, cadmium, copper and arsenic in solution was determined using AAS. The uptake value at equilibrium was calculated using the following equation:

$$
q_{e}=\frac{V\left(C_{i}-C_{e}\right)}{m}
$$

where, $\mathrm{q}_{\mathrm{e}}$ is the uptake of metal(mg/g); $\mathrm{C}_{\mathrm{i}}$ and $\mathrm{C}_{\mathrm{e}}$ are the initial and equilibrium metal concentrations in the water $(\mathrm{mg} / \mathrm{l})$, respectively; $\mathrm{V}$ is the volume of solution (l); and $\mathrm{m}$ is the mass of adsorbent ( $\mathrm{g}$ ).

Column experiments: Figure 2 shows a schematic diagram of fluidized bed system. The column is $7.5 \mathrm{~cm}$ in diameter and $1 \mathrm{~m}$ length.

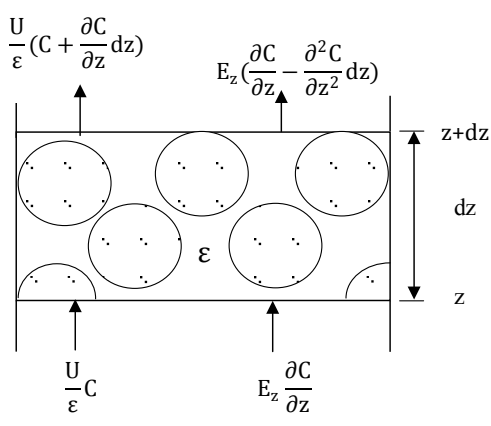

Figure 1: Model of a fluidized bed ion exchange reactor

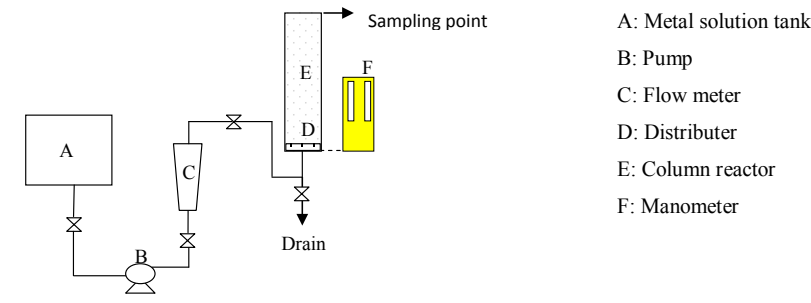

Figure 2: Fluidized bed setup.

A stainless steel distributor of $1 \mathrm{~mm}$ thickness and $0.2 \mathrm{~mm}$ holes dia. was installed at the bottom of the reactor to distribute the influent flow smoothly. The column was partially packed with a known weight of biomass. A U-tube manometer was connected to the reactor to record the pressure drop across the bed, the manometer has an inside diameter of $5 \mathrm{~mm}$ and length is $50 \mathrm{~cm}$. Carbon Tetrachloride $\left(\mathrm{CCl}_{4}\right)$ with density equal $1590 \mathrm{~kg} / \mathrm{m}^{3}$ was used as the manometer liquid. A feed solution containing $50 \mathrm{mg} / \mathrm{l}$ for each metal ion was pumped upward through the column at selected velocities for each particle size. The $\mathrm{pH}$ of each metal solution was adjusted to the best value obtained from the batch experiments. Samples were taken from the effluent from the reactor at time intervals $1,2,5,10,20,30,40,50,60,70,80,90,120,150,180 \mathrm{~min}$. During the experiment, the pressure drop, and fluidized bed height were measured at the corresponding time intervals.

\section{Results and Discussion}

\section{Characterization of algal biomass}

The physical properties of the algal biomass were measured and the results were tabulated in Table 1 . These values are very important in the modeling of breakthrough curves. Figure 3 shows the results of the FTIR analyses of each algal biomass before biosorption (black line), and $\mathrm{Pb}^{2+}$ (gray line), $\mathrm{Cd}^{2+}$ (green line), $\mathrm{Cu}^{2+}$ (blue line) and $\mathrm{As}^{3+}$ (red line) loaded algae. The results of the FTIR spectrum showed that there were different functional groups detected on the surface of the algal biomass. Broad peaks detected in spectra were identified at 3414 $\mathrm{cm}^{-1}$ (hydroxyl and amine groups), 2966 and $2943 \mathrm{~cm}^{-1}$ (alkyl chains), $1797 \mathrm{~cm}^{-1}(\mathrm{C}=0$ of the carboxylic groups or ester groups $), 1647 \mathrm{~cm}^{-1}(\mathrm{C}=\mathrm{O}$ of amide groups), $1427 \mathrm{~cm}^{-1}$ (COO- of the carboxylate groups), and 1300 $\mathrm{cm}^{-1}\left(\mathrm{~S}=\mathrm{O}\right.$ of the sulfonates groups and $\mathrm{COO}^{-}$groups of the fatty acids). The peak value at $1033 \mathrm{~cm}^{-1}$ is attributed to the P-O-C links of the organic phosphate groups. Some bands in the fingerprint regions could be attributed to the phosphate groups. From Figure 3, it can be seen that 


\begin{tabular}{|l|l|l|}
\hline \multicolumn{1}{|c|}{ Parameter } & \multicolumn{2}{c|}{ Value } \\
\hline Particle diameter $(\mathrm{mm})$ & $0.4-0.6$ & $0.6-1$ \\
\hline Bulk density $\left(\mathrm{kg} / \mathrm{m}^{3}\right)$ & 474 & 400 \\
\hline Real density $\left(\mathrm{kg} / \mathrm{m}^{3}\right)$ & 1120 & 1120 \\
\hline Surface area $\left(\mathrm{m}^{2} / \mathrm{g}\right)$ & 1.88 & 1.65 \\
\hline Particle porosity & 0.713 & 0.77 \\
\hline Bed void fraction & 0.577 & 0.642 \\
\hline
\end{tabular}

Table 1: Properties of the algal biomass used in fluidized bed experiments

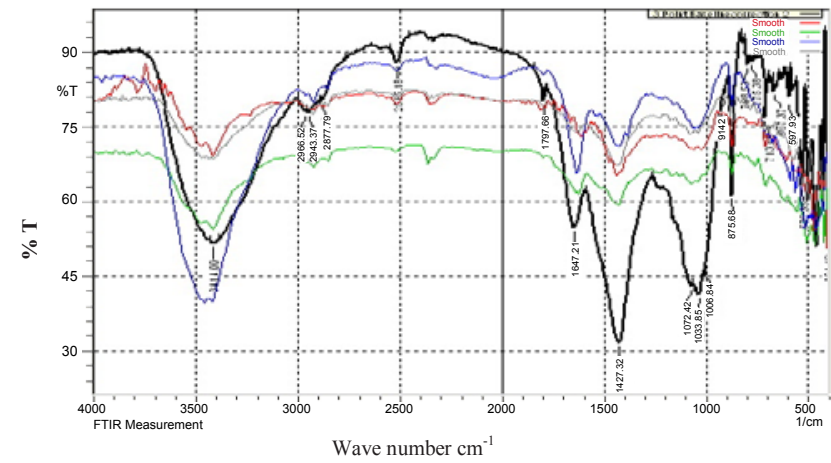

Figure 3: FTIR spectra obtained for algae before biosorption (black), and algae following adsorption of $\mathrm{Pb}^{2+}$ (grey), $\mathrm{Cd}^{2+}$ (green), $\mathrm{Cu}^{2+}$ (blue), $\mathrm{As}^{3+}$ (red).

the $\%$ transmittance $(\% \mathrm{~T})$ values were shifted mainly at hydroxyl and carboxyl groups. These groups are very effective for capturing the heavy metals ions due to their negative charges [21].

\section{Effect of $\mathrm{pH}$}

The $\mathrm{pH}$ of a solution affects metal ion solubility and biosorbent total charge [22]. Normally metal biosorption is directly dependent on $\mathrm{pH}$ value [12]. Figure $4 \mathrm{~b}$ shows the biosorption efficiency of each metal at different $\mathrm{pH}$ values from 2-6. The highest removal of lead, cadmium and arsenic was achieved at $\mathrm{pH}$ of 4 , while at $\mathrm{pH}$ of 5 the highest removal of copper was obtained. The maximum uptake $\left(\mathrm{q}_{\mathrm{e}}\right)$ obtained at the optimum $\mathrm{pH}$ value and $1 \mathrm{~g}$ doses of metals were $44.5,41,39.5$, and $35 \mathrm{mg} / \mathrm{g}$ for $\mathrm{Pb}^{2+}, \mathrm{Cu}^{2+}, \mathrm{Cd}^{2+}$, and $\mathrm{As}^{3+}$, respectively. At $\mathrm{pH}<3$, the active surface sites of the adsorbet were either protonated [23], or dissociated [24], so that lowest biosorption was recorded at these $\mathrm{pH}$ values. Experiments beyond pH 5 were hampered due to precipitation of metals as hydroxides during the biosorption process.

\section{Effect of contact time}

Before the starting of the batch experiments, it was very important to know the required time to reach equilibrium biosorption. In other words, for all batch experiments, the contact time should be sufficient to ensure reaching an equilibrium concentration. Figure 4a shows the results of biosorption efficiency versus contact time for the four metal solutions. It can be seen that a 3 hour contact time is sufficient to reach equilibrium for all four heavy metals.

\section{Effect of Temperature}

The effect of temperature on the equilibrium sorption capacity has been investigated within a temperature range of $10-50^{\circ} \mathrm{C}$. The $\mathrm{pH}$ of each metal solution was fixed at the optimum value determined from the $\mathrm{pH}$ study. Figure $4 \mathrm{c}$ shows the variation of percentage removal with temperature. It was observed that the maximum percentage removal for each of the four metals occurred at $20^{\circ} \mathrm{C}$. Several authors showed that further increases in temperature (above $30^{\circ} \mathrm{C}$ ) lead to a decrease the percentage removal. This decrease in biosorption efficiency may be attributed to: an increase in the relative desorption of the heavy metals from the solid phase to the liquid phase, deactivation of the biosorbent surface, destruction of active sites on the biosorbent surface due to bond disruption $[25,26]$, or due to the weakness of the sorbent active site binding forces and the sorbate species and also between the adjacent molecules of the sorbed phase [27]. From Figure 4c, it can be seen that the variation of temperature from $20-30^{\circ} \mathrm{C}$ has minimal effect on the biosorption process, so that experiments can be carried out at room temperature without adjustment.

\section{Effect of initial concentration}

Figure $4 \mathrm{~d}$ shows the variation of percentage removal at different initial metal concentrations. The results indicated that the percentage removal was not altered greatly from concentrations between 10-50 $\mathrm{mg} / \mathrm{l}$, this may be due to $1 \mathrm{~g}$ of algae containing enough bisorption surfaces and sites for this concentration range [28], thereafter the percentage removal rapidly decreased with the further increase in concentration to $100 \mathrm{mg} / \mathrm{l}$.

\section{Biosorption isotherms}

Biosorption onto algae was assessed and compared to the ion exchange isotherm model. The ion exchange model was fitted with experimental isotherm data at the optimum $\mathrm{pH}$ value for each metal. The ion exchange model parameter (affinity constant, K) were measured and optimized by non-linear regression using the STATISTICA program. The isotherm curves obtained for $\mathrm{Pb}^{2+}, \mathrm{Cd}^{2+}, \mathrm{Cu}^{2+}$ and $\mathrm{As}^{3+}$ are depicted in Figure 5. This figure shows a good fit between the experimental and theoretical data as indicated by the coefficient of determination values $\left(\mathrm{R}^{2}\right)$ obtained. The value of the biomass affinity constant gives a good indication of the biosorption capacity of metals measured [17]. The calculated affinity constants were 16.55, 15.97, 10.52, and 7.45 for $\mathrm{Pb}^{2+}, \mathrm{Cu}^{2+}, \mathrm{Cd}^{2+}$, and $\mathrm{As}^{3+}$ respectively. Yun and Volesky [29] concluded that for divalent ions the major factor affecting the exchange biosorption is the strength of the charge on the ions (electronegativity). The electronegativity (in Pauling scale) of $\mathrm{Pb}^{2+}, \mathrm{Cd}^{2+}, \mathrm{Cu}^{2+}$ and $\mathrm{As}^{3+}$ ions are $2.33,1.69,1.9$, and 2.18 , respectively. $\mathrm{Pb}^{2+}$ demonstrated the
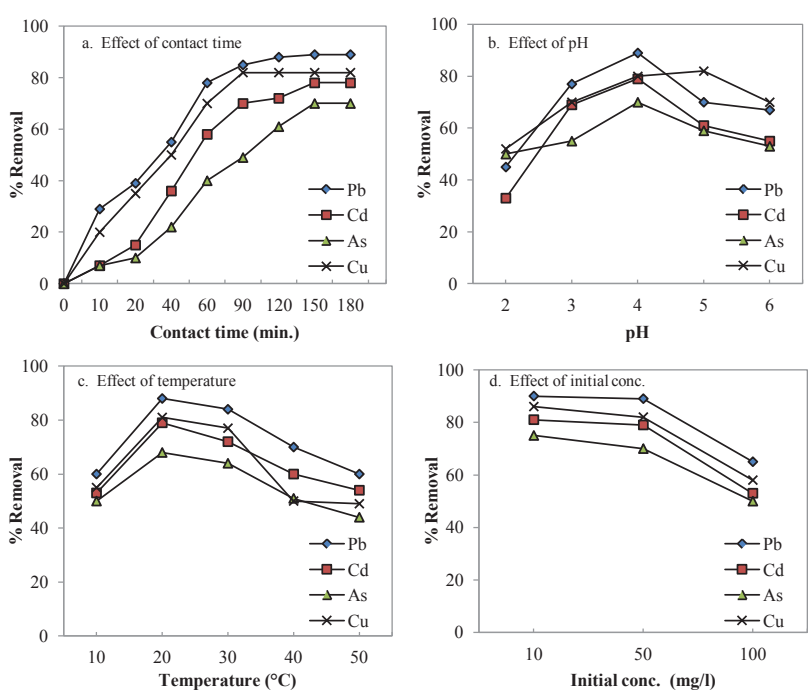

Figure 4: Effects of physical variables on heavy metal biosorption using algal biomass. 

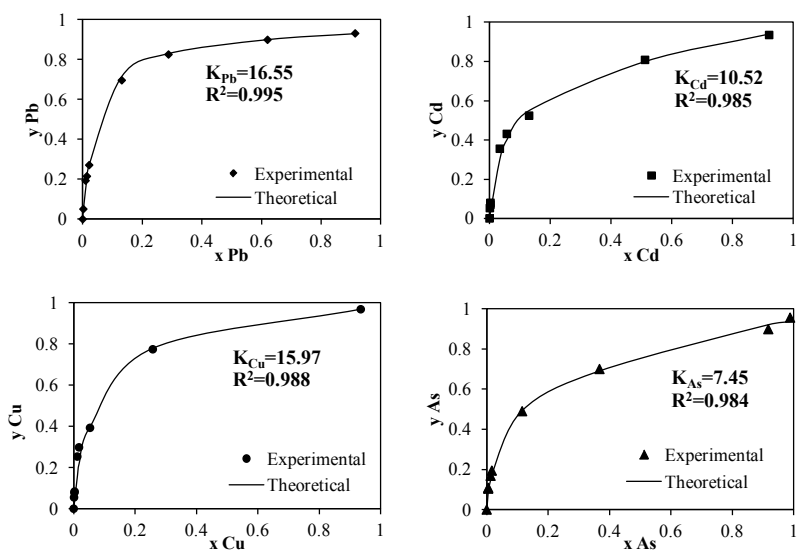

Figure 5: Ion exchange equilibrium isotherm for $\mathrm{Pb}^{2+}, \mathrm{Cd}^{2+}, \mathrm{Cu}^{2+}$, and $\mathrm{As}^{3+}$

highest affinity compared to $\mathrm{Cu}^{2+}, \mathrm{Cd}^{2+}$ and $\mathrm{As}^{3+}$. This can be attributed to the high electronegativity of this metal ion. Despite the fact that $\mathrm{As}^{3+}$ has an electronegativity value greater than $\mathrm{Cd}^{2+}$, and $\mathrm{Cu}^{2+}$ this metal demonstrated lowest affinity value which may be due to it's trivalent ion state needing more exchangeable sites on the biosorbant. Therefore, the sequence of metal biosorption from high to low was calculated as $\mathrm{Pb}^{2+}>\mathrm{Cu}^{2+}>\mathrm{Cd}^{2+}>\mathrm{As}^{3+}$. These findings are in good agreement with the results of Figueria MM et al. [10].

\section{Minimum fluidization velocity}

The minimum fluidization velocity $\left(\mathrm{U}_{\mathrm{mf}}\right)$ was determined experimentally by measuring the pressure drop through the bed of algal particles. The column was partially filled with particles of known mass and then vigorously agitated with water in order to disperse the particles and break down any internal structure. After that the bed was left to settle, and the flow rate increased incrementally from 0 to 100 $1 / h$. At each flow rate increment, the pressure drop was recorded using the manometer. Figure 6 shows the pressure drop across the bed against the superficial fluid velocity on a logarithmic scale. This figure shows that the pressure drop rises linearly below the minimum fluidization velocity in the packed bed region and then plateaus. The $U_{m f}$ can be read from the sharp change in the pressure drop. In addition, it is important in the modeling of continuous systems to be able to establish the relationship between the superficial liquid velocity and the bed void fraction [30]. The bed void fraction $\left(\mathrm{V}_{\varepsilon}\right)$ can be found experimentally by subtracting the volume of the particles $\left(\mathrm{V}_{\mathrm{p}}\right)$ from the total volume of the fluidized bed $\left(\mathrm{V}_{\mathrm{b}}\right)$ using the following equation:

$$
\varepsilon=\frac{V_{\varepsilon}}{V_{b}}=\frac{V_{b}-V_{p}}{V_{b}}=1-\frac{V_{p}}{V_{b}}=1-\frac{m_{p}}{\rho_{p} \cdot V_{b}}
$$

where $m_{p}$ represents the bed mass $(\mathrm{kg}), \rho_{\mathrm{p}}$ is the density of particles $\left(\mathrm{kg} / \mathrm{m}^{3}\right), \mathrm{A}$ is the cross sectional area of the bed $\left(\mathrm{m}^{2}\right), \mathrm{H}$ is the expanded bed height in meter sand depends on the liquid velocity.

Table 2 shows the values of minimum fluidization velocity, plateau pressure drop $(\Delta \mathrm{P})$, bed void fraction, and expanded bed height at minimum fluidization velocity $\left(\mathrm{h}_{\mathrm{mf}}\right)$ for two different size particles that used in column biosorption processes.

\section{Breakthrough curves}

Several authors have proposed generalized correlations to predict the mass transfer coefficient. Park et al. [19] presented the following correlation obtained from the experimental data of a liquid-solid fluidized bed reactor:

$$
\frac{S h \cdot \varepsilon^{0.5}}{S c^{1 / 3}}=0.62 \operatorname{Re}_{p}+0.6
$$

Where: Sh is the Sherwood number $\left(\mathrm{K}_{\mathrm{L}} \cdot \mathrm{d} / \mathrm{D}_{\mathrm{m}}\right), \mathrm{K}_{\mathrm{L}}$ is the mass transfer coefficient $(\mathrm{m} / \mathrm{s}), \mathrm{d}$ is the particle diameter $(\mathrm{m}), \mathrm{D}_{\mathrm{m}}$ is the diffusivity $\left(\mathrm{m}^{2} / \mathrm{s}\right), \mathrm{S}_{\mathrm{c}}$ is the Schmidt number $\left(\mu / \rho . \mathrm{D}_{\mathrm{m}}\right)$, and $\operatorname{Re}_{\mathrm{p}}$ is the Reynolds number for particle.

The diffusivity of each metal can be calculated from the following equation [31]:

$$
D_{m}=2.74 * 10^{-9}\left(M_{w}\right)^{-1 / 3}
$$

where: $\mathrm{M}_{\mathrm{w}}$ is the molecular weight of each metal.

In this work, the previous two equations were used in the modeling of the breakthrough curves. The breakthrough curves for each metal were obtained by plotting $\mathrm{C} / \mathrm{C}_{i}$ versus time. The experimental and predicted breakthrough curves are presented in Figure 7 (a,b,c,d). These figures show a good fit between the experimental and theoretical data according as indicated by the $\mathrm{R}^{2}$ value. The operating time corresponding to $90 \%$ removal (or $C / \mathrm{C}_{\mathrm{i}}=0.1$ ) was chosen as a point for comparison of the removal efficiency of each metal. Also, from Figure 7 (a,b,c,d) it can be seen that $\mathrm{Pb}^{2+}$ has the greatest operating time compared to the other metals. The operating time corresponding to $90 \%$ removal at different operating conditions are listed in Table 3. The metal biosorption from highest to lowest can be arranged as $\mathrm{Pb}^{2+}>\mathrm{Cu}^{2+}>\mathrm{Cd}^{2+}>\mathrm{As}^{3+}$. These findings are in a good agreement with the results of the batch system.

The effect of bed height on the sorption process was investigated for $\mathrm{U}=1.1 \mathrm{U}_{\mathrm{mf}}, \mathrm{C}_{\mathrm{i}}=50 \mathrm{mg} / \mathrm{l}, \mathrm{d}_{\mathrm{p}}=0.4-0.6 \mathrm{~mm}$ and bed weight 50,100 and $150 \mathrm{~g}$ (corresponding to static bed heights of $2.5,5$ and $7.5 \mathrm{~cm}$ ) and the results for breakpoint time were listed in Table 3. These results showed that with increases in the bed height of the algal biomass the time at which an effluent concentration reached equilibrium increased, this is due to the large contact time between the metal solution and particles

\begin{tabular}{|c|c|c|c|c|c|c|}
\hline $\begin{array}{c}\text { Particle size } \\
\mathbf{( m m})\end{array}$ & Mass (g) & $\begin{array}{c}\text { Static } \\
\text { height(cm) }\end{array}$ & $\mathbf{U}_{\mathbf{m f}}(\mathbf{m m} / \mathbf{s})$ & $\boldsymbol{\varepsilon}$ & $\mathbf{\Delta P}(\mathbf{p a})$ & $\left.\mathbf{h}_{\mathbf{m f}} \mathbf{( c m}\right)$ \\
\hline \multirow{3}{*}{$0.4-0.6$} & 50 & 2.5 & 2.27 & 0.79 & 56.3 & 5 \\
\cline { 2 - 7 } & 100 & 5 & 2.27 & 0.79 & 80.1 & 10 \\
\cline { 2 - 7 } & 150 & 7.5 & 2.27 & 0.79 & 112 & 15 \\
\hline \multirow{3}{*}{$0.6-1$} & 50 & 3 & 3.64 & 0.83 & 66.1 & 6 \\
\cline { 2 - 7 } & 100 & 6 & 3.64 & 0.83 & 103.3 & 12 \\
\cline { 2 - 7 } & 150 & 9 & 3.64 & 0.83 & 124.8 & 18 \\
\hline
\end{tabular}

Table 2: Minimum Fluidization Velocity $\left(\mathrm{U}_{\mathrm{mf}}\right)$, Plateau Pressure Drop $(\Delta \mathrm{P})$ and Expanded Bed Height at $U_{m f}\left(h_{m f}\right)$ for two different size particles.

\begin{tabular}{|l|l|c|c|c|c|}
\hline \multirow{2}{*}{ Parameter } & \multirow{2}{*}{ Value } & \multicolumn{4}{|c|}{$\begin{array}{c}\text { Operating time (min.) of } \mathbf{9 0} \% \\
\text { removal for each metal }\end{array}$} \\
\cline { 2 - 6 } & & $\mathbf{P b}^{2+}$ & $\mathbf{C d}^{2+}$ & $\mathbf{C u}^{2+}$ & $\mathbf{A s}^{3+}$ \\
\hline \multirow{3}{*}{ Bed height } & $2.5 \mathrm{~cm}$ & 30 & 17 & 27 & 15 \\
\cline { 2 - 6 } & $5 \mathrm{~cm}$ & 38 & 22 & 36 & 19 \\
\cline { 2 - 6 } & $7.5 \mathrm{~cm}$ & 44 & 37 & 41 & 33 \\
\hline \multirow{2}{*}{ Superficial velocity } & $1.1 \mathrm{U}_{\mathrm{mf}}=2.5 \mathrm{~mm} / \mathrm{s}$ & 38 & 22 & 36 & 19 \\
\cline { 2 - 6 } & $1.5 \mathrm{U}_{\mathrm{mf}}=3.5 \mathrm{~mm} / \mathrm{s}$ & 22 & 14 & 19 & 10 \\
\hline \multirow{3}{*}{ Particle diameter } & $0.4-0.6 \mathrm{~mm}$ & 38 & 22 & 36 & 19 \\
\cline { 2 - 6 } & $0.6-1 \mathrm{~mm}$ & 35 & 19 & 33 & 17 \\
\hline
\end{tabular}

Table 3: Breakpoint time for each metal at different operating conditions. 

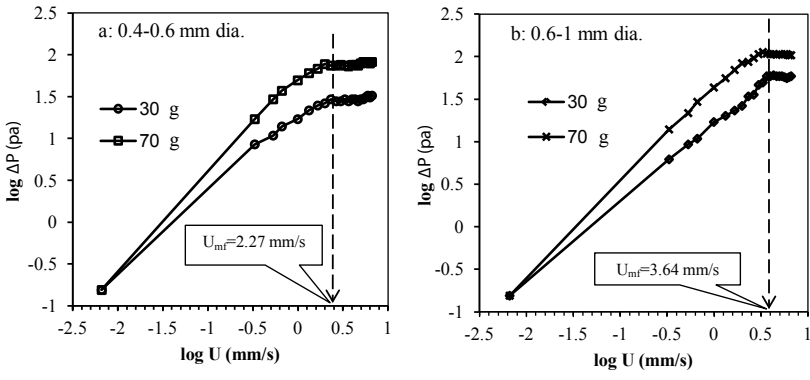

Figure 6: Pressure drop vs. superficial fluid velocity of two ranges of algal biomass particles.
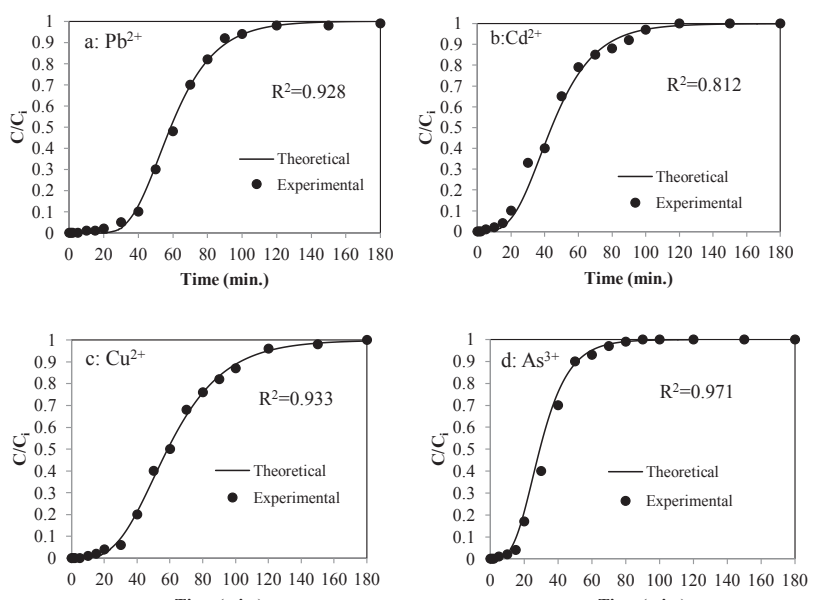

Figure 7: Experimental and theoretical breakthrough curves at $100 \mathrm{~g}$ algal biomass, $\mathrm{pH}=4,25^{\circ} \mathrm{C}, 0.4-0.6 \mathrm{~mm}$ particle diameter and $\mathrm{U}=1.1 \mathrm{U}_{\mathrm{mf}}$

at a high bed height. Smaller bed heights will be saturated in less time. Also, an increase in the bed depth will increase the surface area for the adsorption which will improve the adsorption process.

The fluid velocity is a major parameter in the design of fluidized column due to its effect on the contact time between the particles and the metal solution. Table 3 shows the breakpoint time for each metal at superficial liquid velocity of $\mathrm{U}=1.1 \mathrm{U}_{\mathrm{mf}}$ and $\mathrm{U}=1.5 \mathrm{U}_{\mathrm{mf}}$ bed height $=2.5 \mathrm{~cm}$, and $\mathrm{C}_{\mathrm{i}}=50 \mathrm{mg} / \mathrm{l}$. It can be seen that for all metals the breakthrough point appeared earlier with increasing fluid velocity due to the reduction in contact time for the metal ions to occupy the spaces within the particles.

Finally, the effect of particle diameter was investigated at 0.4-0.6 and 0.6-1 mm particle diameter, $100 \mathrm{~g}$ algal biomass weight, and $1.1 \mathrm{U}_{\mathrm{mf}}$ The results were listed in Table 3 and it can be seen that an increase in particle size causes a decrease of the breakthrough time, which would be anticipated with the decrease in the surface to volume ratio and the subsequent decrease in the surface locations of the particles.

\section{Conclusion}

The present study evaluated the removal of $\mathrm{Pb}^{2+}, \mathrm{Cd}^{2+}, \mathrm{Cu}^{2+}$ and $\mathrm{As}^{3+}$ from wastewater using algal biomass as adsorbent material in fluidized bed reactor. Batch experiments showed that algal biomass can be successfully used for the removal of these metal ions from wastewater.
The maximum biosorption capacities obtained were 44.5, 39.5, 41, and $35 \mathrm{mg} / \mathrm{g}$ for $\mathrm{Pb}^{2+}, \mathrm{Cd}^{2+}, \mathrm{Cu}^{2+}$ and $\mathrm{As}^{3+}$, respectively. Biosorption was found to depend significantly on the $\mathrm{pH}$ of the solution and is optimal at $\mathrm{pH}$ values of 4 and 5. The equilibrium data showed a good fit to the ion exchange model with high correlation coefficients for each metal biosorption. The sequence of calculated affinity constants was $\mathrm{K}_{\mathrm{Pb}}>\mathrm{K}_{\mathrm{Cu}}>\mathrm{K}_{\mathrm{Cd}}>\mathrm{K}_{\mathrm{As}}$. FTIR analyses showed that hydroxyl and carboxyl groups could be significant for capturing these metals.

An ideal plug flow model has been adopted to characterize the fluidized bed reactor; this model fit well to the experimental data. In the fluidized bed system, an increase in the bed depth of algal biomass increased the breakthrough time. Increasing the solution flow rate decreased the breakthrough time due to the decrease in the contact time between the adsorbate and the adsorbent, as well as, at low flow rates the metal ions had a sufficient contact time to occupy the spaces within the particles. Also, it was found that an increase in particle size caused a decrease of the operating time due to the decrease in surface area of large particles relative to small particles.

\section{References}

1. Gin KY, Tang YZ, Aziz MA (2002) Derivation and application of a new model for heavy metal biosorption by algae. Water Res 36: 1313-1323.

2. Wang J, Chen C (2009) Biosorbents for heavy metals removal and their future. Biotechnol Adv 27: 195-226.

3. Kim H, Baek K, Kim B-K, Shin H-J, Yang J-W (2008) Removal characteristics of metal cations and their mixtures using micellar-enhanced ultrafiltration. Korean $\mathrm{J}$ of Chemical Engineering 25: 253-258.

4. McKay G, Ho YS, Ng JCY (1999) Biosorption of Copper from Waste Waters: A Review. Separation \& Purification Reviews 28: 87-125.

5. Romera E, González F, Ballester A, Blázquez ML, Muñoz JA (2007) Comparative study of biosorption of heavy metals using different types of algae. Bioresour Technol 98: 3344-3353.

6. Sulaymon AH, Ebrahim SE, Abdullah SM, Al-Musawi TJ (2012) Removal of lead, cadmium, and mercury ions using biosorption. J Desalination and Water Treatment 24: 344-352

7. Kratochvil D (1997) A study of the metal biosorption process utilizing Sargassum seaweed biomass, Ph.D Thesis, McGill University, Department of Chemical Engineering.

8. Brady JM, Tobin JM, Roux J-C (1999) Continuous fixed bed biosorption of $\mathrm{Cu}^{2+}$ ions: application of a simple two parameter mathematical model. J Chem Technol Biot 74: 71-77.

9. Romera E, González F, Ballester A, Blázquez ML, Muñoz JA (2006) Biosorption with algae: a statistical review. Crit Rev Biotechnol 26: 223-235.

10. Figueria MM, Volesky B, Ciminelli VST, Roddlick FA (2000) Biosorption of metals in brown seaweed biomass. Water Res 34: 196-204.

11. Davis TA, Volesky B, Mucci A (2003) A review of the biochemistry of heavy metal biosorption by brown algae. Water Res 37: 4311-4330.

12. Hossain MA, Ngo HH, Guo WS, Setiadi T (2012) Adsorption and desorption of copper(II) ions onto garden grass. Bioresour Technol 121: 386-395.

13. Fu Y, Liu D (2007) Novel experimental phenomena of fine-particle fluidized beds. Exp Therm Fluid Sci 32: 341-344.

14. Schiewer S, Volesky B (1996) Modeling Multi-Metal Ion Exchange in Biosorption. Environ Sci Technol 30: 2921-2927.

15. Diniz V, Volesky B (2005) Biosorption of La, Eu and Yb using Sargassum biomass. Water Res 39: 239-247.

16. Kratochvil D, Volesky B (1998) Advances in the biosorption of heavy metals Trends Biotechnol 16: 291-300.

17. Diniz V, Weber ME, Volesky B, Naja G (2008) Column biosorption of lanthanum and europium by Sargassum. Water Res 42: 363-371.

18. Ho YS, Huang CT, Huang HW (2002) Equilibrium sorption isotherm for meta ions on tree fern. Process Biochem 37: 1421-1430. 
19. Park YG, Cho SY, Kim SJ, Lee GB, Kim BH, et al. (1999) Mass Transfer in Semi-Fluidized and Fluidized lon-Exchange Beds. Environ Eng Res 4: 71-80

20. ljzerman MM, Falkinham JO, Reneau RB, Hagedorn C (1994) Field evaluation of two colorimetric coliphage detection methods. Appl Environ Microbiol 60: $826-830$

21. Sheng PX, Ting YP, Chen JP, Hong L (2004) Sorption of lead, copper, cadmium, zinc, and nickel by marine algal biomass: characterization of biosorptive capacity and investigation of mechanisms. J Colloid Interface Sci 275: 131-141.

22. Romera E, González F, Ballester A, Blázquez ML, Muñoz JA (2007) Comparative study of biosorption of heavy metals using different types of algae. Bioresour Technol 98: 3344-3353.

23. Lu D, Cao Q, Li X, Cao X, Luo F, et al. (2009) Kinetics and equilibrium of $\mathrm{Cu}(\mathrm{II})$ adsorption onto chemically modified orange peel cellulose biosorbents. Hydrometallurgy 95: 145-152.

24. Lodeiro P, Cordero B, Grille Z, Herrero R, Sastre de Vicente ME (2004) Physicochemical studies of cadmium(II) biosorption by the invasive alga in Europe, Sargassum muticum. Biotechnol Bioeng 88: 237-247.

25. Saleem M, Pirzada T, Qadeer R (2007) Sorption of acid violet 17 and direct red 80 dyes on cotton fiber from aqueous solutions. Colloid Surface A 292: 246-250

26. Meena AK, Mishra GK, Rai PK, Rajagopal C, Nagar PN (2005) Removal of heavy metal ions from aqueous solutions using carbon aerogel as an adsorbent. J Hazard Mater 122: 161-170.

27. Sari A, Tuzen M (2008) Biosorption of cadmium(II) from aqueous solution by red algae (Ceramiumvirgatum): equilibrium, kinetic and thermodynamic studies. $J$ Hazard Mater 157: 448-454.

28. Anwar J, Shafique U, Waheed-uz-Zaman, Salman M, Dar A, et al. (2010) Removal of $\mathrm{Pb}(\mathrm{II})$ and $\mathrm{Cd}(\mathrm{II})$ from water by adsorption on peels of banana Bioresour Technol 101: 1752-1755.

29. Yun YS, Volesky B (2003) Modeling of lithium interference in cadmium biosorption. Environ Sci Technol 37: 3601-3608.

30. Ngian KF, Martin WRB (1980) Bed expansion characteristics of liquid fluidized particles with attached microbial growth. Biotechnol Bioeng 22: 1843-1856.

31. Volesky B, Weber J, Park JM (2003) Continuous-flow metal biosorption in a regenerable Sargassum column. Water Res 37: 297-306. 